\title{
Effects of virus infection on respiration rates of marine phytoplankton and microplankton communities
}

\author{
Yoanna Eissler ${ }^{1, *}$, Elisabeth Sahlsten ${ }^{3}$, Renato A. Quiñones ${ }^{1,2}$ \\ ${ }^{1}$ Centro de Investigación Oceanográfica en el Pacifico Sur-Oriental (COPAS), and ${ }^{2}$ Departamento de Oceanografía, \\ Universidad de Concepción, Casilla 160-C, Concepción, Chile \\ ${ }^{3}$ Swedish Meteorological and Hydrological Institute, Nya Varvet 31, 42671 Västra Frölunda, Sweden
}

\begin{abstract}
The possible influence of viral infection on respiration rates in marine microbial pelagic communities was assessed by means of 3 experiments on respiration rate with viral concentrate addition on single-species cultures of Mantoniella sp. and Micromonas pusilla and another 3 on natural microplankton communities (organisms $<200 \mu \mathrm{m}$ ) from the Kattegat Sea (Åstol) and the Baltic Sea. Coastal surface seawater samples were taken during cruises of the RVs 'Ancylus' and 'Argos' during winter and spring 2000. Approximately 50 to $70 \mathrm{l}$ of seawater were concentrated by ultrafiltration. The experiments were started by adding a viral particle concentrate to a container with algae or a natural microplankton community; a control container was kept free of the viral concentrate addition. Oxygen concentration determinations were carried out on each treatment and control to measure respiration rates throughout the incubation period. The in vivo chlorophyll a fluorescence was also monitored as an indication of algal infection. The rates of respiration indicated that the addition of the viral particle concentrate affected the respective metabolisms of the Mantoniella sp. and Micromonas pusilla cultures as well as natural microplankton communities. Viral infection decreased the Mantoniella sp. respiration rate (by $96 \%$ ) and increased the Micromonas pusilla respiration rate (by $235 \%$ ). Hence, if our results can be extrapolated to nature, then, at least in a bloom situation, the fate of primary production and carbon fluxes could be strongly modulated by viral infection. The addition of a viral particle concentrate to the microplankton community generated complex responses in terms of respiration rates, which increased (by $84 \%$ ) or remained similar to the controls. Our results suggest that viral infection of microplanktonic organisms could be one of the factors significantly modifying pelagic carbon fluxes.
\end{abstract}

KEY WORDS: Respiration - Marine viruses $\cdot$ Microalgae $\cdot$ Virus infection $\cdot$ Kattegat $\cdot$ Baltic Sea Resale or republication not permitted without written consent of the publisher

\section{INTRODUCTION}

Viruses or virus-like particles (VLP) may be numerically the most dominant life form in the oceans, with concentrations from $10^{6}$ to $>10^{8}$ viruses $\mathrm{ml}^{-1}$ (e.g. Bergh et al. 1989, Proctor \& Fuhrman 1990, Hara et al. 1991, Wommack et al. 1992). Viral infection may cause about $30 \%$ of total mortality in marine cyanobacteria and up to $60 \%$ in heterotrophic marine bacteria in coastal and offshore environments (Proctor \& Fuhrman 1990). Furthermore, several studies have demonstrated that natural virus populations can consist of different viruses infective to many algal groups, such as coccolithophorids (Bratbak et al. 1995), picoflagellates (Chen \& Suttle 1995, Cottrell \& Suttle 1995, Suttle \& Chan 1995), and dinoflagellates (Tarutani et al. 2001), and that viruses seem to be very specific to algal species or strains (Sahlsten 1998, Cottrell \& Suttle 1991).

Experimental studies have shown that the addition of viral concentrates to a variety of important marine primary producers can reduce primary production by as much as $78 \%$ (Suttle et al. 1990, Suttle 1992), indi- 
cating that, in addition to grazing and nutrient limitations, virus infections could be a factor regulating the phytoplankton community structure and primary productivity in the oceans (Suttle et al. 1990). In fact, if viruses regulate primary production, they could also affect the inverse process, i.e. respiration, not only of phytoplankton but also of heterotrophic organisms. Accordingly, if viruses affect both processes, then they could be a significant factor in modulating total metabolism in the pelagic system.

Here, we present results from a study in which we determined whether respiration rates of single phytoplankton species and natural microplankton communities are affected by the addition of viral concentrates.

\section{MATERIALS AND METHODS}

Sampling. Coastal surface seawater samples were taken during a cruise of the RV 'Ancylus' and RV 'Argos' during winter and spring 2000 (Table 1, Fig. 1). The samples were collected using a water pump previously cleaned by flushing with seawater. The samples were then kept in polypropylene containers ( 30 l) that had been cleaned by pre-soaking with $0.1 \mathrm{~N} \mathrm{HCl}$ and then rinsed several times with distilled and ultrapure water. Some of the seawater sampled was used for concentrating viruses and some was used as nat-

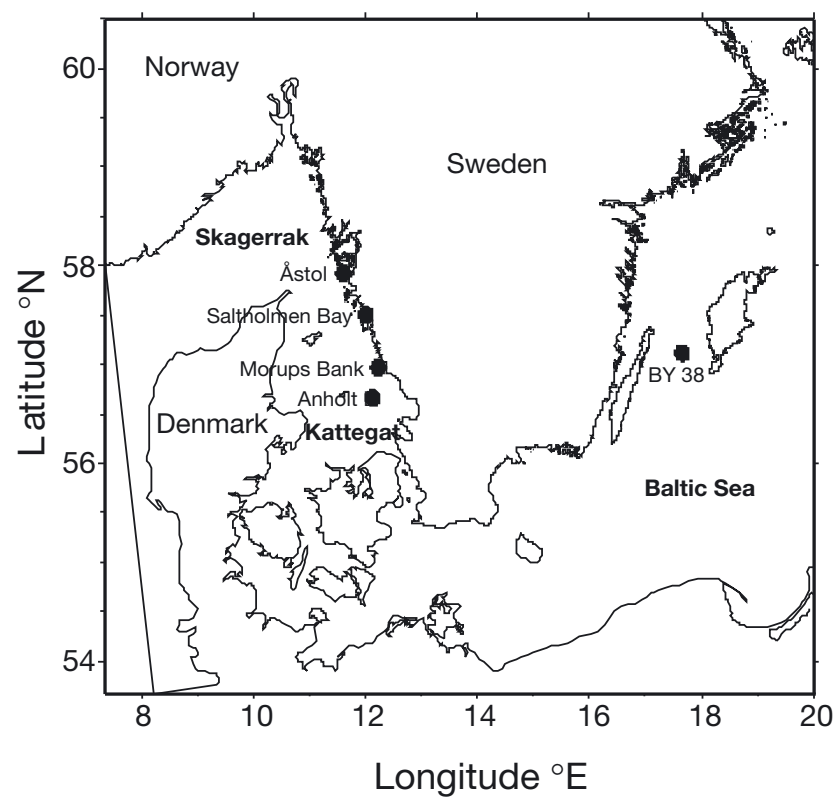

Fig. 1. Map showing the stations where the samples were taken ural microplankton assemblages in the experiments (Table 1).

Concentrating viruses from seawater. In order to remove all plankton cells and most of the bacterioplankton, approximately 50 to 701 of surface seawater were pre-screened and filtered (vacuum pressure $<130 \mathrm{~mm} \mathrm{Hg}$ ) through two $142 \mathrm{~mm}$ diameter filters allocated in series: (1) Whatman GF/C glass-fibre filter, (2) $0.45 \mu \mathrm{m}$ Durapore filter (Millipore). The filtrate was concentrated approximately 250 -fold by ultrafiltration using a 30000 MW cut-off ultrafilter (Amicon Spiral Cartridge Model S1Y30) as described by Suttle et al. (1991). Viral concentrates were checked qualitatively using transmission electron microscopy to make sure that there was no significant bacterial contamination.

Algae cultures. Algal cultures of Mantoniella sp. (Prasinophyceae), Micromonas pusilla (Prasinophyceae), Chaetoceros muelleri (Bacillariophyceae) and Prorocentrum minimum (Dinophyceae) were obtained from the phytoplankton culture collection of the Department of Marine Botany at the University of Göteborg. The cells were grown in a medium prepared with autoclaved artificial seawater (Harrison et al. 1980) enriched with f/2 nutrients (Guillard 1975) and modified by the addition of $5 \mathrm{mM}$ Tris- $\mathrm{HCl}(\mathrm{pH}=7.7)$ and $10 \mathrm{nM}$ $\mathrm{Na}_{2} \mathrm{SeO}_{3}$ (Cottrell \& Suttle 1991). The cultures were incubated at approximately $20^{\circ} \mathrm{C}$ under a $12: 12 \mathrm{~h}$ light:dark cycle using artificial light ('daylight fluorescent tubes', $80 \mu \mathrm{E} \mathrm{s}^{-1} \mathrm{~m}^{-2}$ ).

Test for viral infection and viral isolation. To carry out single-alga respiration experiments, it was necessary to find an alga-host to lytic-virus relationship. An inoculate of viral particle concentrate obtained from the Baltic Sea (Stn BY38, Fig. 1) was added to 4 algal species (Chaetoceros muelleri, Micromonas pusilla, Mantoniella sp., and Prorocentrum minimum) to investigate possible lytic virus infections in any of the algae species. The algae cultures were grown in $10 \mathrm{ml}$ polypropylene screw-capped glass tubes under the conditions described above; 5 tubes of exponentially growing cultures were inoculated with $0.5 \mathrm{ml}$ of viral 
particle concentrate, and 5 tubes were kept as controls. Algae growth was monitored by daily measurements of in vivo chlorophyll a fluorescence with a fluorometer (Turner Model 111) equipped with a blue (Corning 560) primary filter and a red (Corning 2-64) secondary filter. It was considered that a viral infection, indicated by lysis of the algae, had taken place when a drastic decrease of in vivo fluorescence, reaching values close to zero, was observed while the fluorescence of the controls stayed high. Cultures that had not lysed after $18 \mathrm{~d}$ were considered to be unsuitable hosts for the viruses.

After viral infection was detected, $1 \mathrm{ml}$ of each of the lysed cultures was filtered through $0.20 \mu \mathrm{m}$ membrane filters (MiniSart sterile, Sartorius) and used to inoculate a new set of exponentially growing cultures. This procedure was repeated to enrich and isolate the specific algal virus that was infective to the alga species. The enriched viruses, called stock viruses, were stored in the dark at $4^{\circ} \mathrm{C}$ until use. The infectivity of the stock virus sample was checked before each experiment. The host-specificity of each isolated virus was also checked for each of the 4 algae species used. However, it is important to note that the stock virus samples were not completely pure, as the infective viral particles were not isolated and purified.

Transmission electron microscope (TEM) and flow cytometric analyses. Samples were stored at $4^{\circ} \mathrm{C}$ before analysis and prepared for TEM observation as described by Bratbak \& Heldal (1993). Particles were harvested onto electron microscope grids $\left(\mathrm{Ni}_{1}\right.$ 400mesh carbon-coated formvar film) by centrifugation for 30 min at $200000 \times g$ in a Beckman SW 41 swing-out rotor. The grids were positively stained with $2 \%$ uranyl acetate and viewed in a JEOL 100CX TEM at $30000 \times$ magnification. Flow cytometric analysis was performed as described by Marie et al. (1999). A FACSort flow cytometer (Becton Dickson) equipped with an air-cooled laser providing $15 \mathrm{~mW}$ at $488 \mathrm{~nm}$ and with the standard filter setup was used. For enumeration of virus and bacteria, the sample was diluted up to 1000 -fold, the discriminator was set to green fluorescence, and the sample was analysed by flow cytometry for 1 to $4 \mathrm{~min}$ at a delivery rate of $50 \mu \mathrm{min}^{-1}$.

Experimental design for single-species cultures. The effect of virus addition on respiration rates was assessed using single-species cultures of Mantoniella sp. and Micromonas pusilla: 2 experiments were carried out on the Mantoniella sp. cultures and 1 on the $M$. pusilla cultures. Prior to each experiment, all material used was carefully cleaned with ultra-pure water and then sterilised by autoclaving at $120^{\circ} \mathrm{C}$. In addition, bacterioplankton communities were sorted out by gently filtering $(<130 \mathrm{~mm} \mathrm{Hg})$ the algae culture, first through a glass-fibre filter (Whatman GF/C) and then
Table 2. In situ and mean $\pm \mathrm{SD}$ experimental incubation temperatures $\left({ }^{\circ} \mathrm{C}\right)$

\begin{tabular}{|lrcc|}
\hline Expt & In situ & Incubation & Mean difference \\
\hline 1 & 21.6 & $21.7 \pm 1.0$ & 0.8 \\
2 & 22.2 & $22.3 \pm 0.5$ & 0.4 \\
3 & 18.3 & $18.3 \pm 0.4$ & 0.4 \\
4 & 3.3 & $15.5 \pm 1.1$ & 12.2 \\
5 & 4.3 & $17.2 \pm 1.6$ & 12.9 \\
6 & 11.4 & $21.5 \pm 1.6$ & 10.2 \\
\hline
\end{tabular}

through a $1 \mu \mathrm{m}$ pore-size polycarbonate filter (Nuclepore). The filtrate was used operationally as the 'bacterioplankton community'.

The experiment was started by adding $50 \mathrm{ml}$ of viral stock to 2 carboys containing $20 \mathrm{l}$ of the algae culture and bacterioplankton community respectively. In Expt 1, crude viral concentrate from Stn BY38 was used (Table 1). In Expts 2 and 3, the stock corresponded to enriched Mantionella sp. and Micromonas pusilla-specific viruses respectively. As controls we kept $20 \mathrm{l}$ of both fractions without any virus addition. The algae cultures with and without viruses were incubated under a 12:12 light:dark cycle while the temperature was kept at $21.4 \pm 1.6^{\circ} \mathrm{C}$ (Table 2). The bacterioplankton community was incubated in the dark. Oxygen samples were taken from each carboy to measure respiration rates throughout the incubation period. The in vivo chlorophyll a fluorescence was monitored during every experiment for evidence of infection (Sequoia-Turner Fluorometer Model 450).

Experimental design for natural microplankton assemblages. We carried out 3 microplanktonic experiments to determine the effect of viral infection on respiration rates of natural microplankton assemblages (organisms $<200 \mu \mathrm{m}$ ).

The experimental design was nearly the same as that used in the single-alga experiments. First, the bacterioplankton was separated from the microplankton community by filtering through a $1 \mu \mathrm{m}$ Nuclepore polycarbonate filter and keeping the filtrate. Then 15 to 201 of the microplankton community as well as 15 to $20 \mathrm{l}$ of the bacterioplankton community were infected with 40 to $50 \mathrm{ml}$ of the natural viral particle concentrates (Table 1). We kept 201 of both fractions without any virus addition as an experimental control. The microplankton communities - with and without viruses were incubated under the conditions described above for single-species experiments. It was not possible to maintain the incubation temperature very close to the in situ temperature (Table 2). Oxygen samples were taken from each carboy to measure respiration rates throughout the incubation period. The in vivo chlorophyll a fluorescence was monitored (Sequoia-Turner 
Fluorometer Model 450) during each experiment for evidence of phytoplankton infection.

Respiration rates. Dissolved oxygen measurements were carried out using the Winkler method (Carpenter 1965) and the analytical procedures suggested by Knap et al. (1993) and by Culberson (1991). The variation coefficient of the dissolved oxygen measurements was $0.1 \%$.

As zero samples $\left(t_{0}\right)$, we fixed 5 replicates of each treatment. The remaining bottles ( 5 replicates per control and 5 per virus treatment) were incubated for 21 to

Mantoniella sp. infection (27/6-12/7)

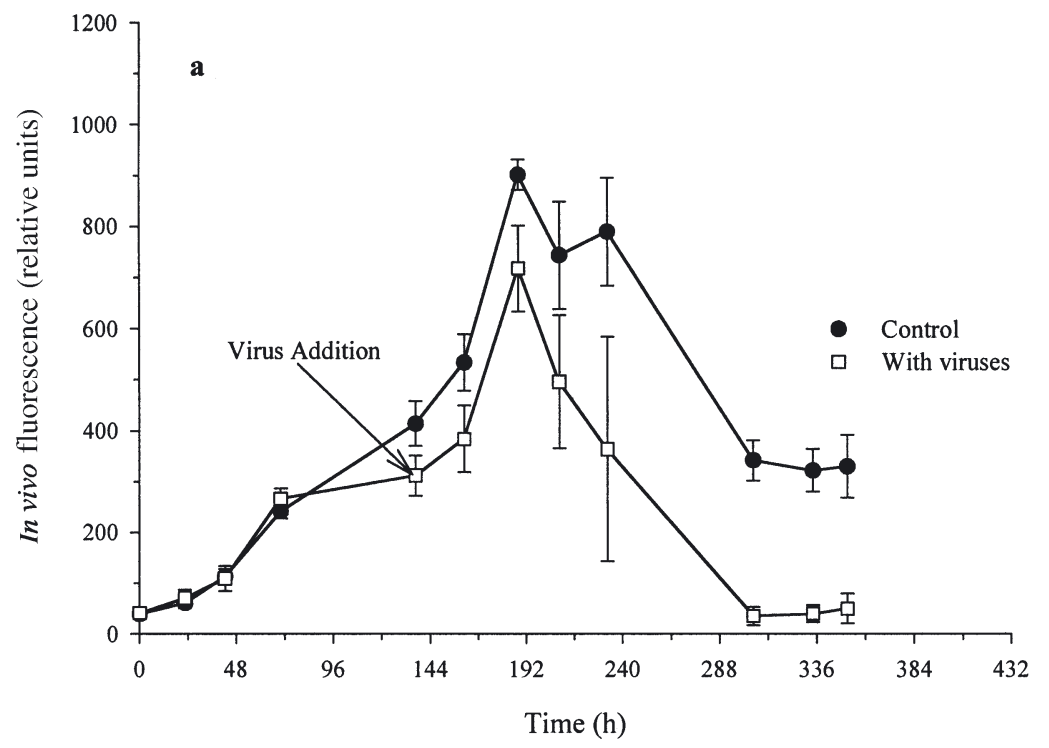

Micromonas pusilla infection (11/7-28/7)

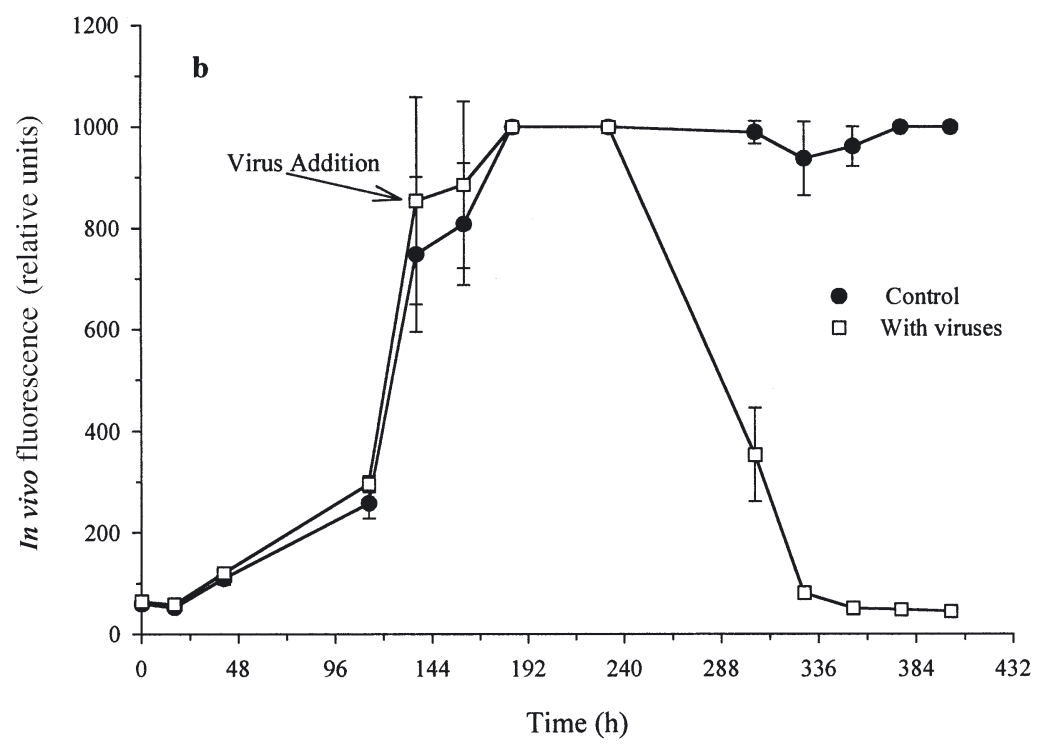

Fig. 2. Mantoniella sp. and Micromonas pusilla. Effect of virus infection on in vivo fluorescence
$24 \mathrm{~h}$ in the dark in glass oxygen bottles until fixation at the final time $\left(t_{\mathrm{f}}\right)$. Microplanktonic respiration is estimated as the difference of dissolved oxygen between $t_{\mathrm{o}}$ and $t_{\mathrm{f}}$. In addition, 5 oxygen samples of the control or virus-infected treatments were fixed after 10 to $12 \mathrm{~h}$ incubation to check the linear decay of oxygen during the incubation period.

The standard error was used to statistically compare respiration rates between the controls and the treatments (i.e. with viral concentrate addition), and was calculated according to Zar (1996). Respiration rates were considered to be different when the standard errors of the measurements did not overlap.

\section{RESULTS}

Viral infection of single-species cultures

From the 4 species inoculated with the viral particle concentrate from Stn BY38 (Fig. 1), only Mantoniella sp. (Fig. 2a) and Micromonas pusilla (Fig. 2b) were infected after 51 and $96 \mathrm{~h}$ of viral addition respectively (i.e. 188 and $232 \mathrm{~h}$ of incubation time respectively). Isolates of the viruses able to infect Mantoniella sp. and M. pusilla did not infect Chaetoceros muelleri or Prorocentrum minimum.

\section{Mantoniella sp. virus}

The lysate (i.e. viruses freed from cells) of Mantoniella sp. obtained from the first experiment was examined by transmission electron microscopy. The estimated size of the viruses ranged from 100 to $133 \mathrm{~nm}$ and the size of the Mantoniella sp. scales ranged from 200 to $280 \mathrm{~nm}$ in diameter (Fig. 3). This virus did not present a tail and was hexagonal in shape, indicating icosahedral symmetry. The same viral sample examined by flow cytometry presented $1.2 \times 10^{8}$ virus particles $\mathrm{ml}^{-1}$ and $1.5 \times$ $10^{8}$ bacteria $\mathrm{ml}^{-1}$.

\section{Respiration in single-species cultures}

During both experiments with Mantoniella sp., respiration rates always differed between the virus-treated culture and the untreated control (Fig. 4a,b), the difference 


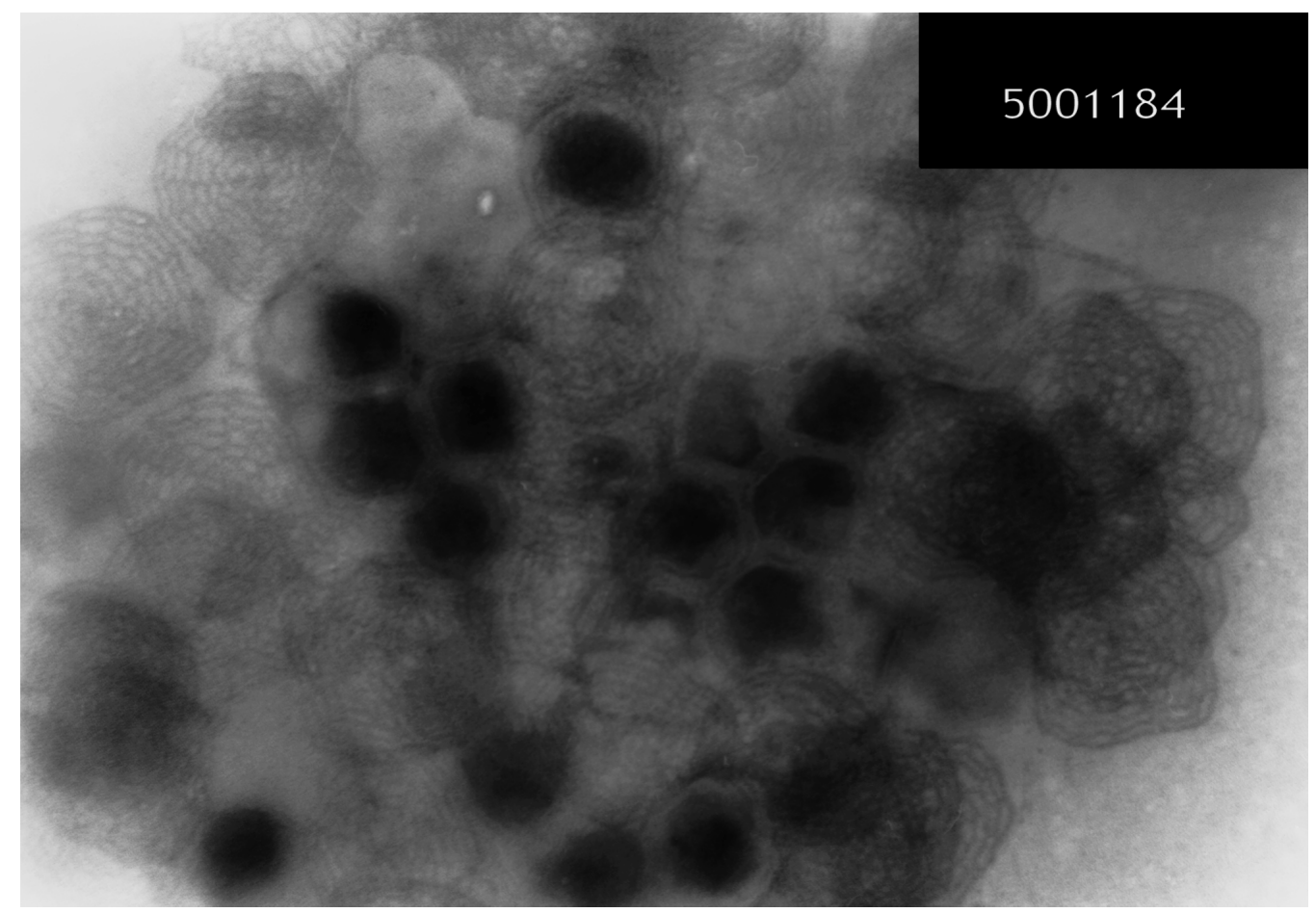

Fig. 3. Mantoniella sp. Electron microscope photograph showing viruses and scales (supplied by M. Heldal)

being as high as $96 \%$. The bacterioplankton respiration rates with and without viral addition were consistently much lower than those of Mantoniella sp. and they did not present changes during the incubation period (Fig. 4a,b).

During Expts 1 and 2, the in vivo fluorescence of the virus-treated Mantoniella sp. culture strongly decreased after 112 and $15 \mathrm{~h}$ of viral addition respectively. The in vivo fluorescence of the infected cultures corresponded, for Expts 1 and 2, to 2 and $0.6 \%$ of the fluorescence of the controls (Fig. 4d,e). The respiration rates of Micromonas pusilla with and without viral addition differed, with a comparative increment of the respiration rate as high as $235 \%$ in the virus-treated M. pusilla culture (Fig. 4c). The in vivo fluorescence started to decrease in the virus-treated fraction after $144 \mathrm{~h}$ incubation; the in vivo fluorescence of the infected culture was $18 \%$ of the fluorescence of the control at the end of the experiment (Fig. 4f).

\section{Respiration in natural microplankton assemblages}

We carried out 3 respiration experiments to verify the possible effect of viral infection on microplankton and natural bacterioplankton communities.

During Expt 4 (Fig. 5a), there was no difference in respiration rates between the microplankton commu- nity subjected to the addition of the viral particle concentrate (MV) and the control without the added viral particle concentrate (MC). The respiration rate of the bacterioplankton control community (BC) was higher $(58 \%)$ than that of the bacterioplankton with the added viral particle concentrate (BV).

In Expts 5 (Fig. 5b) and 6 (Fig. 5c), MV presented a maximum respiration difference over MC of $67 \%$ $(180 \mathrm{~h})$ and $84 \%$ (255 h) respectively. Moreover, the MV respiration rates in Expt 6 showed a maximum decrease of about $31 \%$ in comparison with MC. BC respiration rates were as much as 40 and $45 \%$ higher than BV in Expts 5 and 6 respectively.

The MC in vivo fluorescence did not differ from that of the MV during Expt 4 (Fig. 5d) and an increase in the in vivo fluorescence was seen during the incubation period. During Expt 5 (Fig. 5e), the in vivo fluorescence of MV and MC increased and the MV fluorescence was higher than that of the MC until $246 \mathrm{~h}$ after the addition of the viral particle concentrate. In Expt 6, there was no apparent effect of the viral particle concentrate addition on the in vivo fluorescence (Fig. 5f).

\section{DISCUSSION}

Our results provide evidence that the addition of a viral particle concentrate can affect respiration rates of 
Expt. 1 Respiration Rate Mantoniella sp. vs Time

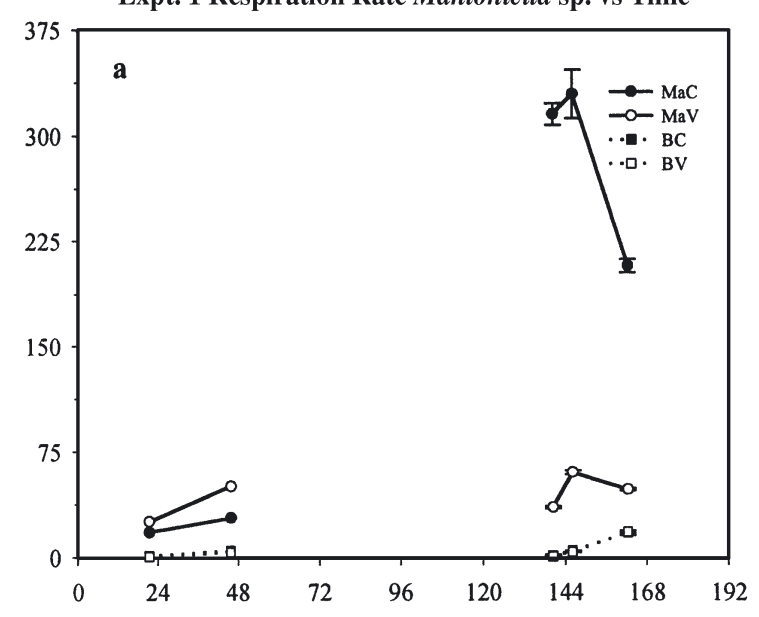

Expt. 2 Respiration Rate Mantoniella sp. vs Time

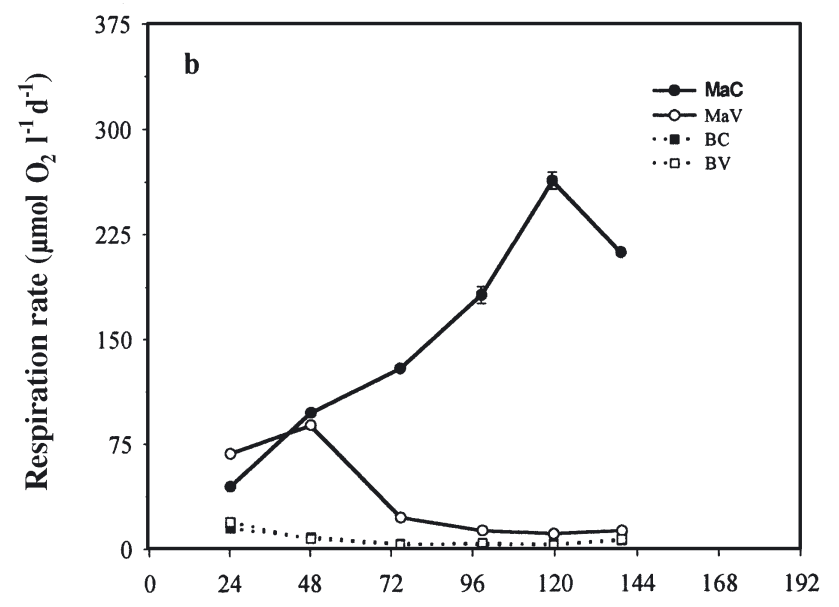

Expt. 3 Respiration Rate Micromonas pusilla vs Time

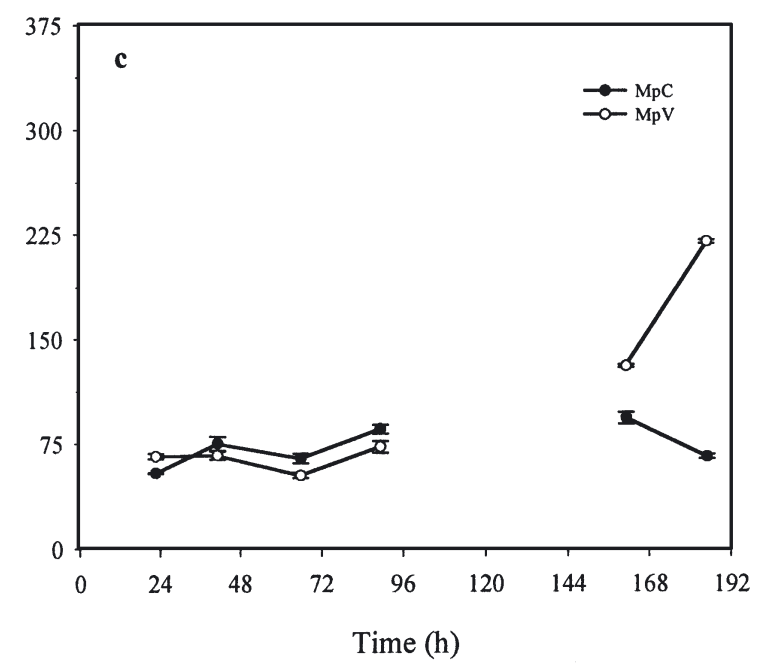

Expt. 1 Mantoniella sp. Fluorescence vs Time

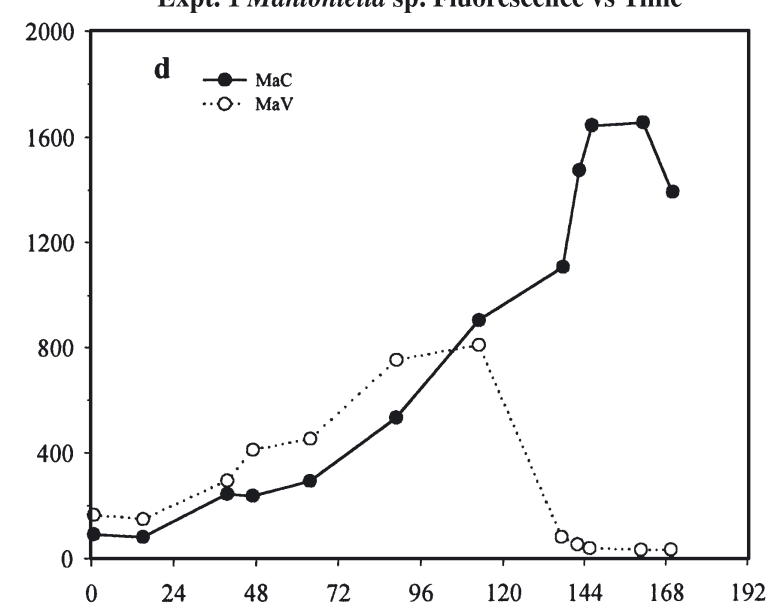

Expt. 2 Mantoniella sp. Fluorescence vs Time

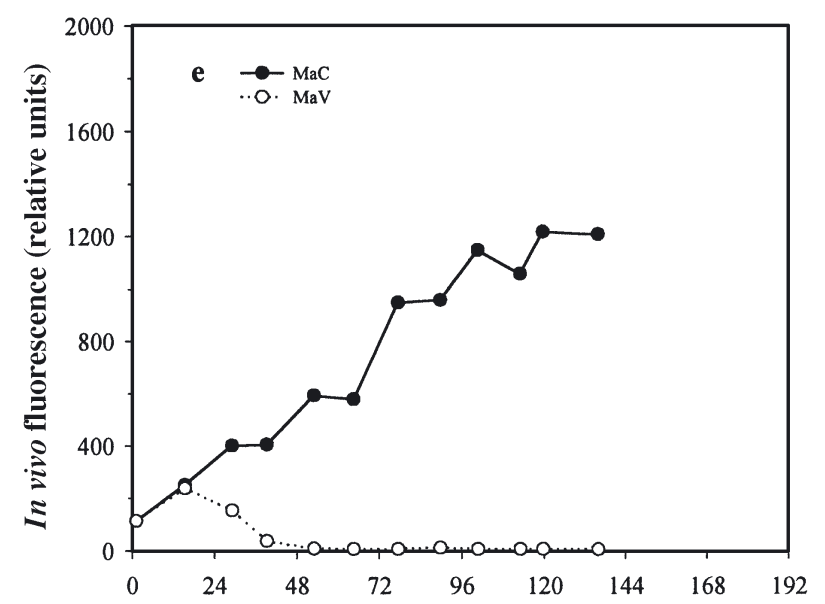

Expt. 3 Micromonas pusilla Fluorescence vs Time

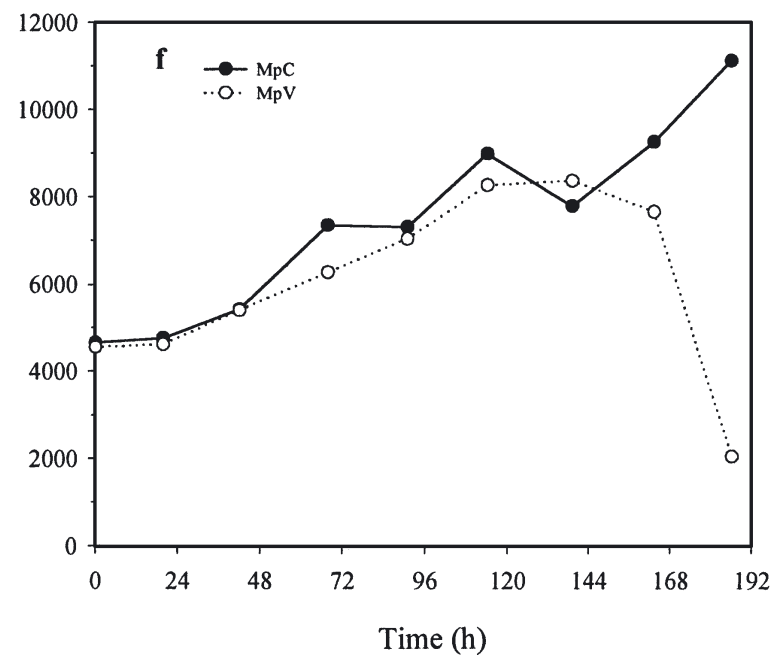

Fig. 4. Mantoniella sp. and Micromonas pusilla culture. Respiration rates and in vivo fluorescence (relative units) as a funtion of incubation time for single-alga treatments (Expts 1 to 3); 2 experiments were carried out for Mantoniella sp., 1 for Micromonas pusilla. $\mathrm{MaC}, \mathrm{MaV}$ : Mantoniella sp. control and virus-added experiments respectively; BC: bacterioplankton control; $\mathrm{BV}$ : bacterioplankton with added virus; MpC, MpV: Micromonas pusilla control and virus-added experiments repectively 
Expt. 4 Community Respiration Rate vs Time

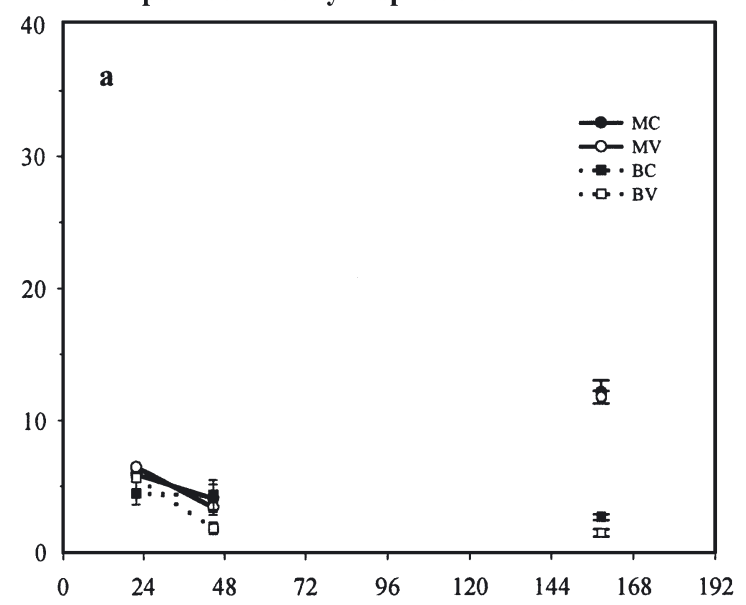

Expt. 5 Community Respiration Rate vs Time

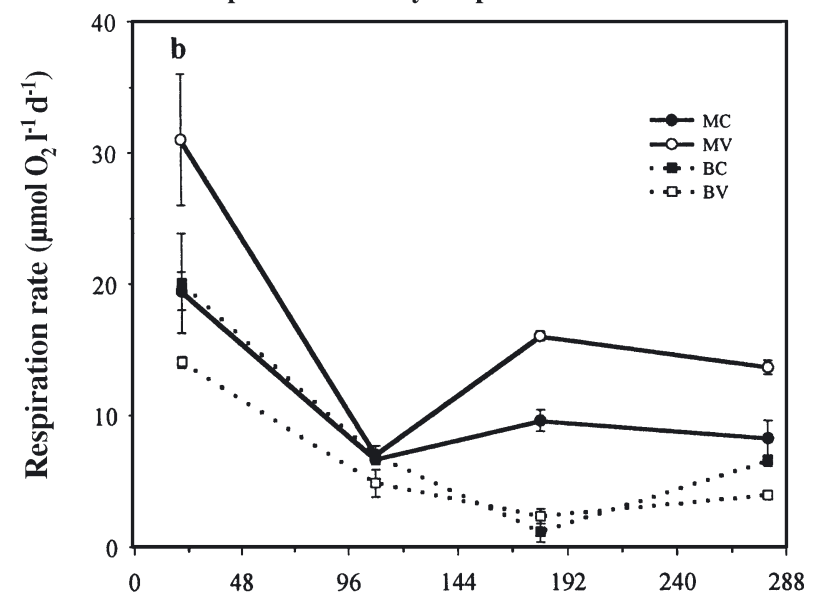

Expt. 6 Community Respiration Rate vs Time

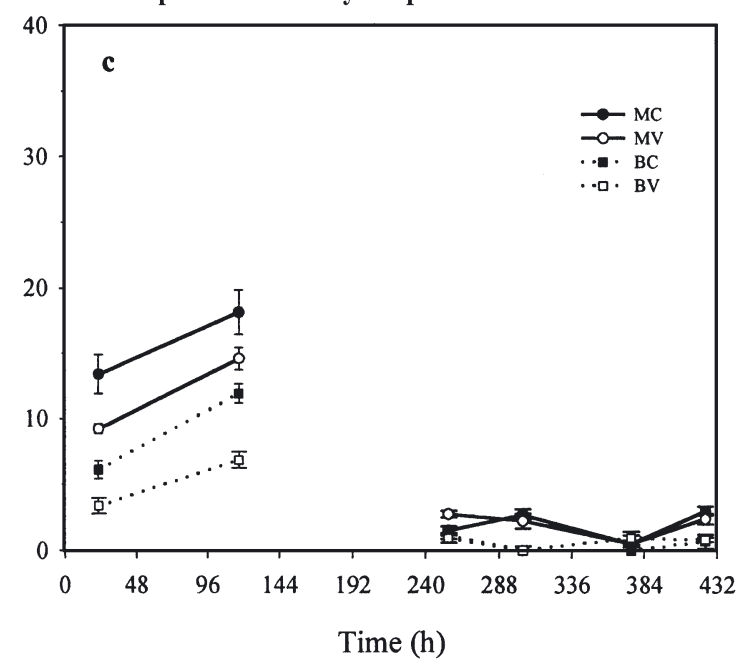

Expt. 4 Community Fluorescence vs Time

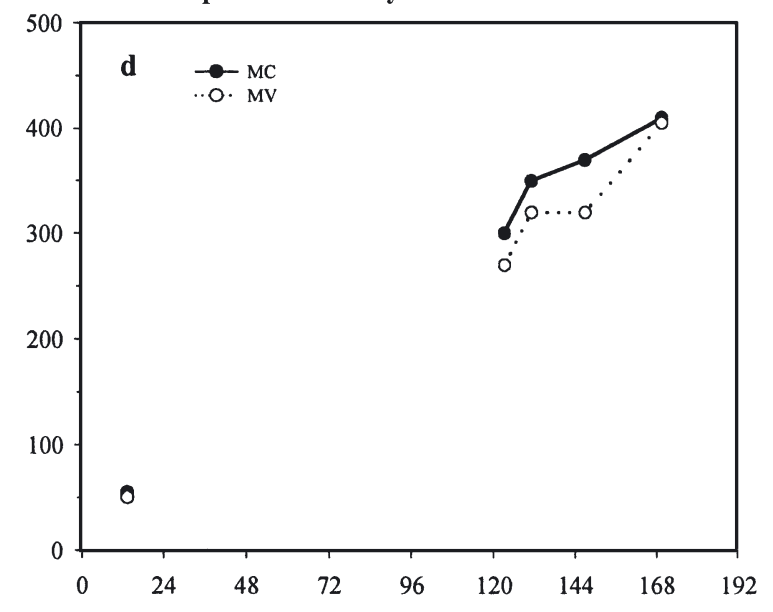

Expt. 5 Community Fluorescence vs Time

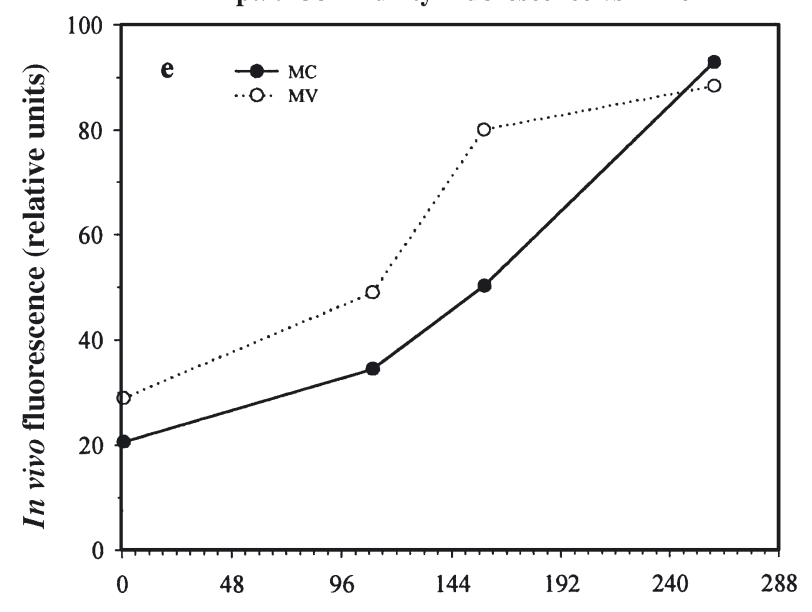

Expt. 6 Community Fluorescence vs Time

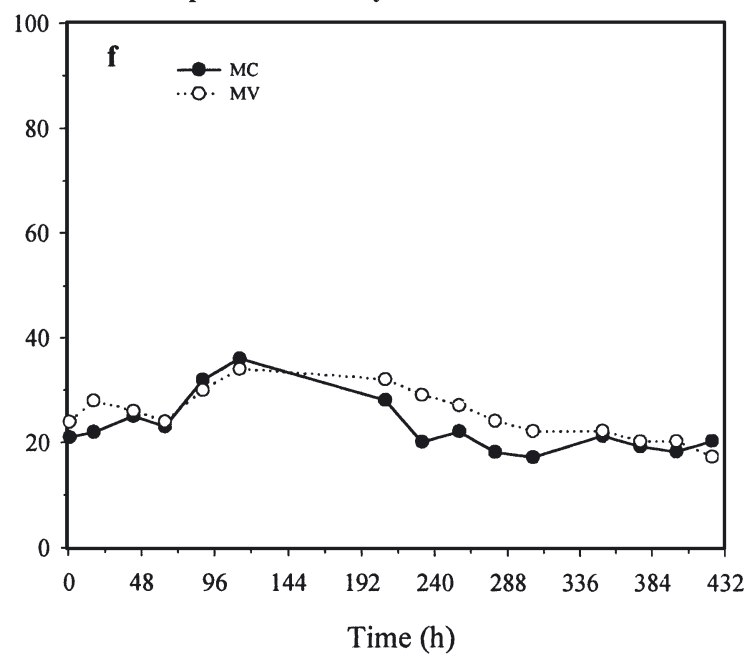

Fig. 5. Microplankton community respiration rate and in vivo fluorescence (relative units) as a function of incubation time for natural microplankton assemblages (Expts 4 to 6) in 3 replicate experiments. MC, MV: control and virus-added experiments respectively; $\mathrm{BC}$ : bacterioplankton control; BV: bacterioplankton with added virus 
natural microplankton communities as well as singlespecies algae cultures. Nevertheless, the response is far from simple. In the case of the experiments on Mantoniella sp., the respiration rate decreased by as much as $96 \%$ after inoculating the culture with a viral particle concentrate, while in the case of the Micromonas pusilla culture, the respiration rate increased by as much as $235 \%$.

We found that viruses infecting Mantoniella sp. and Micromonas pusilla are species-specific and co-exist in the same environment as their host. The size and shape of the Mantoniella sp. virus (Fig. 3) was very similar to an earlier virus found by Sahlsten \& Shaohong (unpubl. data) and to a Micromonas pusilla virus described by Cottrell \& Suttle (1991) and Sahlsten (1998). Viruses infecting Mantoniella sp. and Micromonas pusilla seem to be abundant in the environment (Cottrell \& Suttle 1991, Sahlsten unpubl. data), reflecting the abundance and wide distribution of their hosts.

The effect of viral addition on respiration rates was consistent in Mantoniella sp. experiments even when different assemblages of viruses (i.e. Stn BY38 and enriched Mantoniella sp.-specific viruses) were used to infect the algae. The ratio between the number of Mantoniella sp.-specific viruses and the number of Mantoniella sp. cells was much higher when a stock virus sample was added than when the algal culture was inoculated with a concentrate from a natural viral assemblage. The different specific virus:host ratios used in the 2 experiments with Mantoniella sp. could explain the difference in time-lag before any infection was detected.

On the other hand, we do not know the causes for the slower viral infection rate observed in the Micromonas pusilla experiment in comparison to others described in the literature (Cottrell \& Suttle 1991), but it is possible that the viral concentrate had diminished its infectivity capacity due to storage (Cottrell \& Suttle 1995). Unfortunately, we do not have more information about this virus and it may differ from other viruses previously described for M. pusilla (Cottrell \& Suttle 1991, 1995, Sahlsten 1998).

The only information published to date about the effect of viruses on respiratory rates of marine algae is the work of Robledo et al. (1994) on the pluricellular filamentous brown-algae Feldmannia irregularis and F. simplex (Phaeophyceae). Robledo et al. (1994) showed that viral infection slightly decreased the respiration rates of both algae species. This trend is similar to the effect on the culture of Mantoniella sp. On the other hand, respiration rates of plants may increase or decrease depending on the kind of viral infection developed (Matthews 1981, 1991). The Micromonas pusilla experiment showed an increment in respiration rates when viral concentrates were added, suggesting that virus infection increased cell metabolism before lysis.

In spite of the significant decrease in respiration rates due to massive cell lysis observed after 112 and $15 \mathrm{~h}$ of incubation in Expts 1 and 2 respectively (Fig. 4a,b), there was always detectable respiratory activity in the virus-treated Mantoniella sp. culture, indicating the presence of cells surviving the virus infection. In fact, we observed the recovery of the cultures approximately $1 \mathrm{wk}$ after lysis (results not shown).

Our results show that the respiration rate of Mantoniella sp. can decrease between 5 and 26 times due to viral infection, suggesting that, during a bloom of this species, the fate of primary production and carbon fluxes may be strongly modulated by viral infection on a weekly time scale. Whether viruses may be a potential modulating factor for the biogeochemical fluxes in other species remains open.

The results of virus infection experiments with natural microplankton communities may be influenced by viral host-specificity. There are many reports in the literature indicating that viruses are host-specific (Milligan \& Cosper 1994, Jacobsen et al. 1996) and even strain-specific in the marine environment (Suttle \& Chan 1993, Nagasaki \& Yamaguchi 1997, Sahlsten 1998). For instance, Sahlsten (1998) found that 10 isolated viruses were species-specific to Micromonas pusilla and even strain-specific to $1-3$ of the 6 strains of $M$. pusilla. A recognisable effect of viral infection on community respiration rates can only be detected if those affected are very abundant microplankton species.

Respiration rates of natural microplankton communities reacted to the addition of viral concentrates by increasing (84\%, Expts 5 and 6), decreasing (31\%, Expt 6), or remaining equal (Expt 4). The causes of these responses are not clear, but at least 2 hypotheses emerge: (1) since viruses are host-specific, it is possible that there was no infection at all during the incubation, or that just 1 or a few non-abundant species were infected and, accordingly, the effect on community respiration rates would not be detectable; or (2) after virus infection, the metabolism of the host species increased before lysis took place. The first hypothesis seems most likely, as fluorescence followed the same trend and even increased both in the controls and in the virusadded communities in 2 of the experiments (Fig. 5d,e), while in the last experiment the fluorescence decreased slightly (Fig. 5f).

Other possible explanations for the absence of a noticeable change in respiration rates after the viral concentrate addition, are: (1) the viral concentrate could have been too dilute, diminishing the virus-host encounter rate and, therefore, not allowing infection to take place; (2) low infective efficiency of the viruses 
could be due to the effect of exposure during incubation to light and particulate organic matter (Wommack \& Colwell 2000); (3) virus concentrates may have degraded during storage so that the rates of viral impact were underestimated.

In Expt 5, the respiration rate of the microplanktonic community seemed to be affected by viral addition, but fluorescence did not decrease, suggesting that the viruses may have infected only heterotrophic organisms. There is evidence of viral lysis in marine heterotrophic nanoflagellates (Nagasaki et al. 1993, Garza \& Suttle 1995) and the presence of lytic viruses in marine heterotrophic nanoflagellates (Nagasaki et al. 1995). Thus, it is possible that, in the viral community concentrated from the Baltic Sea, there may have been viruses present capable of infecting heterotrophic microorganisms of the microplanktonic community. In this case, the viral infection might have had the effect of increasing cellular metabolism, reflected in an increment of respiration rates of the infected organisms. Plant hosts have been known to experience virus-induced synthesis of new proteins, some of which are biologically active substances (enzymes, toxins, etc.) able to interfere with the normal metabolism of the host (Agrios 1970). A similar example is the effect produced by oncogenic viruses in heterotrophic cells of mammals (Murray et al. 1997).

Fuhrman \& Suttle (1993) indicated that bacterial respiration can increase $33 \%$ because of the enhanced effect of bacterial lysis on the availability of dissolved organic matter due to viral infection. There may have been a similar effect in the Micromonas pusilla experiment (Fig. 4c,f) where the respiration rate increased at the time when the fluorescence showed a drastic drop. The rise in the respiration rate might be explained by a few remaining uninfected cells being stimulated by nutrient addition from the lysed cells. In contrast, our results suggest that bacterioplankton respiration rates treated with viral concentrate addition may decrease by about $58 \%$ and, therefore, the loss terms (i.e. bacterial mortality/lysis, depression of respiration rates) could be much higher than the gain terms (i.e. metabolic increase due to more availability of energetic substrates).

Unfortunately there was an important temperature difference $\left(10.2\right.$ to $\left.12.9^{\circ} \mathrm{C}\right)$ between in situ and incubation conditions during the experiments (Table 2). However, our goal was to assess whether virus infection affects respiration rates and not to estimate the respiration rate at the in situ temperature. The critical comparison was that between respiration rates of microplankton communities treated with, and those not treated with, viral concentrate addition.

In terms of carbon fluxes, our results show that viral infection can affect respiration rates as much as pri- mary productivity (i.e. decrease in $78 \%$; Suttle et al. 1990). However, in the case of the viral effect on respiration rates, the infection can increase or decrease respiration rates by as much as 84 and $31 \%$ respectively. Recently, Eissler \& Quiñones (2003) observed similar trends whilst conducting experiments to test the effect of viral concentrate addition on respiration rates of microplankton communities from a shallow bay in the Humboldt Current System. Thus, viral infection on microplanktonic organisms could be one of the factors significantly modifying pelagic carbon fluxes, especially by altering the gross production-to-community respiration ratio $(\mathrm{P} / \mathrm{R})$. Further research is needed to understand the role of viral infection in both marine photoautotrophic and microheterotrophic organisms and their mediated biogeochemical fluxes in order to attain a more complete picture of the microbial food web and, consequently, a better understanding of the paths of matter and energy in the pelagic ecosystem.

Acknowledgements. We wish to thank Gunnar Bratbak and Mikal Heldal (Department of Microbiology, University of Bergen, Norway) for Y.E.'s training and access to transmission electron microscopy and flow cytometry. We thank Monica Appelgren and Bengt Karlson (Department of Botany, Göteborg University) for providing the algal cultures. We also acknowledge the personnel of the Swedish Meteorological and Hydrological Institute (SMHI) Oceanographic Laboratory for assistance in the field. The SMHI and the Department of General and Marine Microbiology of the Göteborg University (Sweden) facilitated the installations and equipment necessary for conducting the experiments. This research was funded by the 'VIRTUE Project: host specificity and algalvirus interaction' (Swedish Wallenberg Foundation) and by the FONDAP Program (CONICYT, Chile). Y.E. thanks the Swedish Institute for giving her a fellowship to conduct research in E.S.'s laboratory.

\section{LITERATURE CITED}

Agrios GN (1970) Plant pathology. Academic Press, New York, London

Bergh O, Borsheim KY, Bratbak G, Heldal M (1989) High abundance of viruses found in aquatic environments. Nature 340:467-468

Bratbak G, Hendal M (1993) Total count of viruses in aquatic environments In: Kemp PF, Sherr BF, Sherr EB, Cole JJ (eds) Current methods in aquatic microbial ecology. Lewis Publishers, London, p 135-138

Bratbak G, Levasseur M, Michaud S, Cantin G, Fernández E, Heimdal BR, Hendal M (1995) Viral activity in relation to Emiliana huxleyi blooms: a mechanism of DSMP release? Mar Ecol Prog Ser 128:133-142

Carpenter JH (1965) The Chesapeake Bay Institute technique for the Winkler oxygen method. Limnol Oceanogr 10: 141-143

Chen F, Suttle CA (1995) Amplification of DNA polymerase gene fragments from viruses infecting microalgae. Appl Environ Microbiol 61:1274-1278

Cottrell MT, Suttle CA (1991) Wide-spread occurrence and clonal variation in viruses which cause lysis of a cosmo- 
politan, eucaryotic marine phytoplankter, Micromonas pusilla. Mar Ecol Prog Ser 78:1-9

Cottrell MT, Suttle CA (1995) Genetic diversity of algal viruses which lyse the photosynthetic picoflagellate Micromonas pusilla (Prasinophyceae). Appl Environ Microbiol 61: 3088-3091

Culberson CH (1991) Dissolved oxygen. WHP operations and methods-July 1991. College of Marine Studies, University of Delaware, Newark

Eissler Y, Quiñones RA (2003) The effect of viral concentrate addition on the respiration rate of Chaetoceros gracilis cultures and microplankton from a shallow bay (Coliumo, Chile). J Plankton Res 25(8):927-938

Fuhrman JA, Suttle CA (1993) Viruses in marine planktonic systems. Oceanography 6:51-63

Garza DR, Suttle CA (1995) Large double-stranded DNA viruses which cause the lysis of a marine heterotrophic nanoflagellate (Bodo sp.) occur in natural marine viral communities. Aquat Microb Ecol 9:203-210

Guillard RRL (1975) Culture of phytoplankton for feeding marine invertebrates. In: Smith WL, Chanley MH (eds) Culture of marine invertebrate animals. Plenum Press, New York, p 29-60

Hara S, Terauchi K, Koike Y (1991) Abundance of viruses in marine waters: assessment by epifluorescence and transmission electron microscopy. Appl Environ Microbiol 57: 2731-2734

Harrison PJ, Warwes RE, Taylor FJR (1980) A broad spectrum artificial seawater medium for coastal and open ocean phytoplankton. J Phycol 16:28-35

Jacobsen A, Bratbak G, Heldal M (1996) Isolation and characterization of a virus infecting Phaeocystis pouchetii (Prymnesiophyceae). J Phycol 32:923-927

Knap AH, Michaels AF, Dow RL, Johnson RJ and 8 others (1993) BATS methods manual, Version 3. US Joint Global Ocean Flux Study (JGOFS) Planning Office, Woods Hole, MA

Marie D, Brussaard CPD, Thyrhaug R, Bratbak G, Vaulot D (1999) Enumeration of viruses in marine samples by flow cytometry. Appl Environ Microbiol 65:45-52

Matthews REF (1981) Effects on plant metabolism. In: Matthews REF (ed) Plant virology. Academic Press, New York, p 358-392

Matthews REF (1991) Disease symptoms and effects on metabolism. In: Matthews REF (ed) Plant virology. Academic Press, San Diego, p 380-442

Milligan KL, Cosper EM (1994) Isolation of virus capable of lysing the brown tide microalga, Aureococcus anophagefferens. Science 266:805-807

Editorial responsibility: Otto Kinne (Editor),

Oldendorf/Luhe, Germany
Murray PR, Kobayashi GS, Pfaller MA, Rosenthal KS (1997) Microbiología médica. Harcourt Brace, Madrid

Nagasaki K, Yamaguchi M (1997) Isolation of a virus infectious to the harmful bloom causing microalga Heterosigma akashiwo. Aquat Microb Ecol 13:135-140

Nagasaki K, Ando M, Imai I, Itakura S, Ishida I (1993) Viruslike particles in an apochlorotic flagellate in Hiroshima Bay, Japan. Mar Ecol Prog Ser 96:307-310

Nagasaki K, Ando M, Imai I, Itakura S, Ishida Y (1995) Viruslike particles in unicelular apochlorotic microorganisms in the coastal water of Japan. Fish Sci 61:235-239

Proctor LM, Fuhrman JA (1990) Viral mortality of marine bacteria and cyanobacteria. Nature 343:60-62

Robledo DR, Sosa PA, Garcia-Reina G, Müller DG (1994) Photosynthetic performance of healthy and virus-infected Feldmannia irregularis and F. simplex (Phaeophyceae). Eur J Phycol 29:247-251

Sahlsten E (1998) Seasonal abundance in Skagerrak-Kattegat coastal waters and host specificity of viruses infecting the marine photosynthetic flagellate Micromonas pusilla. Aquat Microb Ecol 16:103-108

Suttle CA (1992) Inhibition of photosynthesis in phytoplankton by the submicron size fraction concentrated from seawater. Mar Ecol Prog Ser 87:105-112

Suttle CA, Chan AM (1993) Marine cyanophages infecting oceanic and coastal strains of Synechoccus: abundance, morphology, cross-infectivity and growth charasteristics. Mar Ecol Prog Ser 92:99-109

Suttle CA, Chan AM (1995) Viruses infecting the marine Prymnesiophyte Chrysochromulina spp.: isolation, preliminary characterisation and natural abundance. Mar Ecol Prog Ser 118:275-282

Suttle CA, Chan AM, Cottrell MT (1990) Infection of phytoplankton by viruses and reduction of primary productivity. Nature 347:467-469

Suttle CA, Chan AM, Cottrell MT (1991) Use of ultrafiltration to isolate viruses from seawater which are pathogens of marine phytoplankton. Appl Environ Microbiol 57:721-726

Tarutani K, Nagasaki K, Itakura S, Yamaguchi M (2001) Isolation of a virus infecting the novel shellfish-killing dinoflagellate Heterocapsa circularisquama. Aquat Microb Ecol 23:103-111

Wommack KE, Colwell RR (2000) Virioplankton: viruses in aquatic ecosystems. Microbiol Mol Biol Rev 64:69-114

Wommack KE, Hill RT, Kessel M, Russek-Cohen E, Colwell RR (1992) Distribution of viruses in the Chesapeake Bay. Appl Environ Microbiol 58:2965-2970

Zar JH (1996) Biostatistical analysis, 3rd edn. Prentice Hall, Englewood Cliffs, NJ

Submitted: October 11, 2001; Accepted: August 26, 2003

Proofs received from author(s): October 27, 2003 